\title{
The Relationship between Emotional Intelligence and Marketing Effectiveness and its Impact on Market Spread (Loyalty, Product Positioning and Mental Image) For Multi-national Companies
}

\author{
Dr. Eman Wadie Abdel Halim \\ Assistant Professor of Business Administration \\ El Shorouk Academy \\ Arab Republic of Egypt
}

\begin{abstract}
This paper investigates the relationship between emotional intelligence of executive managers in multinational companies and marketing effectiveness, highlighting the dimensional marketing growth in developing and developed countries alike. Will loyalty of consumers to the product remain the same when moving between countries - given the fact that the mental image and market position of the product vary between different markets. Multi-stage random sampling used in this study and the research sample was calculated using percentage $(n=158)$.

The results of this research uncovered a positive correlation between variables of emotional intelligence, specially self-management and self-awareness of executive managers, and all the variables of marketing effectiveness. It also asserted a positive correlation between all variables of emotional intelligence and marketing effectiveness - with a higher influence of marketing effectiveness variables on customer loyalty, product position and mental image.
\end{abstract}

Keywords: emotional intelligence, marketing effectiveness, customer loyalty, product position and mental image, market spread in Egypt.

\section{Introduction}

Emotional intelligence (EI) is based on understanding one's feelings and the feelings of others. The individuals' understanding of their personal interests and those of others means increasing communication and mutual influence. Hence, emotional intelligence has gained a great popularity and traction in marketing and leadership fields. It is interesting to know that $60 \%$ of global enterprises use the emotional intelligence tests in the initial screening process of managers, sales representatives and other personnel (Michael Marshall, 2015). Coca-Cola was one of the first companies to train their managers on emotional intelligence. The performance of mangers who received El training leaped to $15 \%$ versus other managers who did not receive the training and whose performance lagged by $15 \%$. This means that the performance gap between the two groups was $30 \%$. Not to mention, the volume of sales and production of companies that apply El jumped to $25 \%$ higher than its counterparts in the same industry (Keller, 2009).

\footnotetext{
* This article was submitted in November 2018, accepted for publishing in January 2019 and published on March 2021.

(c) Arab Administrative Development Organization- League of Arab States, 2021, pp 345-368، DOI: 10.21608/aja.2021.29926
} 
This research builds on the modified theory of emotional intelligence by Goleman (2001) with all its four variables and also the five requirements of marketing effectiveness defined by Kotler (1997). Previous studies that used these two models will be reviewed in Table 1. In addition, the study will explain in details the procedures of the experimental study and their outcomes. In the end, results will be discussed and analyzed to introduce research suggestions and recommendations.

An inventory was made of all the executive managers working in multi-national companies in different industrial sectors in Egypt as categorized by the General Authority for Investment and Free Zones in Egypt (refer to research sample - Table No.). A research tool was designed and divided into four main parts branching into 45 items. Part 1 includes five demographic items that aim at identifying some descriptive data of the respondents - namely the companies' executive managers. Part 2 comprises the four variables of emotional intelligence (EI) as defined by Goleman's Modified Model (2001): self-awareness, self-control, social awareness and relationship management. Whereas Part 3 comprises variables of marketing effectiveness (Kotler, 1977) including these five: client philosophy, integration, supervision of marketing functions, collecting sufficient marketing data, defining a strategic orientation and finally operational efficiency. The last part, Part 4, measures the marketing spread of international companies under study in three main fields: consumer loyalty, mental image and product positioning from the perspectives of the research sample. In this respect, some applicable models were tested such as Charles, 2015; Rust et al. 1995; Zeithaml, Berry and Parasuraman, 1996; Staton et al., 2012 and Cronin and Taylor, 1992.

The researcher will follow the inductive method in data analysis by studying the results and exploring the correlation and influential relations between research variables, Emotional intelligence( Self-awareness - Self-control- Social awareness- Relationship management) with the effectiveness of marketing (Client philosophy - Integration and supervision of key marketing functions- Collecting sufficient marketing information - Strategic guidance - Operational efficiency) and Market spreading (Consumer loyalty - Market position Mental image).

\section{Research Question}

Normally, some executive managers of multi-national companies change companies' policies and marketing strategies from one country to the other in order to achieve compatibility with consumers' tastes, needs, demographic features and environmental variables pertinent to those countries. The researcher thus questions the effect of emotional intelligence variables and marketing effectiveness on corporate spread in different markets and on the continuation of consumer loyalty to the product; does this loyalty change if the consumer travels from one country to another - given the fact that sometimes the mental image and product position might vary from one market to another? Will purchasing decisions of the product persist wherever the consumer resides whether locally or internationally, in a developing or developed country?

\section{Literature Review}

The following table is a preview of the most important previous studies that cover the three main research interests: emotional intelligence variables, marketing effectiveness and market spread. 


\section{Emotional intelligence}

\begin{tabular}{|c|c|c|}
\hline$\overline{A u}$ & Field of Study/Objective & Results \\
\hline $\begin{array}{c}\text { Amir and } \\
\text { Vahid (2015) }\end{array}$ & $\begin{array}{l}\text { Researchers studied the relationship be- } \\
\text { tween emotional intelligence variables } \\
\text { and some marketing exchange opera- } \\
\text { tions identified in the study relating to } \\
\text { customer directions; impact on sales; and } \\
\text { level of sales representatives' adaptabili- } \\
\text { ty with marketing and sales policies in in- } \\
\text { surance and real estate sectors both. }\end{array}$ & $\begin{array}{l}\text { The study pointed out evident variances between emo- } \\
\text { tional intelligence variables in both insurance and real } \\
\text { estate sectors, specifically in the first } 3 \text { variables which are } \\
\text { Self-awareness, Self- management and Social Awareness. } \\
\text { The only point of agreement was Relationship Manage- } \\
\text { ment which, according to Goleman's Model, consists of } \\
\text { six efficiencies: inspiration, influence, development of } \\
\text { others, and motivation for change, conflict management, } \\
\text { group work and cooperative work. }\end{array}$ \\
\hline $\begin{array}{l}\text { Andree and } \\
\text { Paula (2014) }\end{array}$ & $\begin{array}{l}\text { The aim of this study is to evaluate the } \\
\text { current definition and importance of } \\
\text { emotional intelligence of employees in } \\
\text { the real estate sector. }\end{array}$ & $\begin{array}{l}\text { The study concluded that there is a positive relationship } \\
\text { between emotional intelligence, corporate profitability } \\
\text { and customer satisfaction. It was recommended that com- } \\
\text { panies should adopt emotional intelligence concepts since } \\
\text { it has the ability to boost management skills in different in- } \\
\text { dustries and in all business fields in general. }\end{array}$ \\
\hline $\begin{array}{l}\text { Blair Kidwell } \\
\text { et al. (2014) }\end{array}$ & $\begin{array}{l}\text { The researchers conducted three field } \\
\text { studies to explore the effect of emotion- } \\
\text { al intelligence during the marketing ex- } \\
\text { change operation on three components: } \\
\text { relationship management, sales perfor- } \\
\text { mance and customer service in insurance } \\
\text { and real estate sectors. }\end{array}$ & $\begin{array}{l}\text { The study advised that sales representatives who possess } \\
\text { high emotional intelligence skills not only achieve high- } \\
\text { er profits but they are also more capable of maintaining } \\
\text { their customers' loyalty and understanding reasons be- } \\
\text { hind customer behavior changes. The study confirmed } \\
\text { that emotional intelligence positively affects salesper- } \\
\text { sons performance and their cognitive abilities. The study } \\
\text { recommended selecting employees who possess emo- } \\
\text { tional intelligence and using innovative training methods } \\
\text { to develop their sale skills and market knowledge. }\end{array}$ \\
\hline $\begin{array}{l}\text { Teresa Fer- } \\
\text { nandes and } \\
\text { João Proença } \\
\text { (2013) }\end{array}$ & $\begin{array}{l}\text { The study explored relations in consum- } \\
\text { er markets that depend on emotions, } \\
\text { awareness and intention, which have a } \\
\text { leading role in maintaining consumers' } \\
\text { loyalty to products. }\end{array}$ & $\begin{array}{l}\text { Researchers concluded that motives based on aware- } \\
\text { ness explain the results of functional relations such as } \\
\text { re-purchase intentions; and that motives based on emo- } \\
\text { tions explain other phenomenon such as altruism, good } \\
\text { intentions and compliance, which represent higher } \\
\text { forms of loyalty and devotion on the consumer's side to } \\
\text { the product and the brand wherever the market might } \\
\text { be. }\end{array}$ \\
\hline $\begin{array}{l}\text { Blair Kidwell } \\
\text { et al. (2011) }\end{array}$ & $\begin{array}{l}\text { This study was conducted on the Amer- } \\
\text { ican Exchange Markets and American } \\
\text { sales representatives in order to explore } \\
\text { the effect of emotional intelligence on } \\
\text { selling banking products and services. }\end{array}$ & $\begin{array}{l}\text { The study concluded that emotional intelligence is an } \\
\text { important factor in many professional fields, and that } \\
\text { sales representatives could achieve positive results if } \\
\text { they are capable of using the element of emotions. One } \\
\text { of the research recommendations was setting new crite- } \\
\text { ria to measure emotional intelligence through the pro- } \\
\text { cess of hiring sales representatives. }\end{array}$ \\
\hline
\end{tabular}




\section{Marketing Effectiveness}

\begin{tabular}{|c|c|c|}
\hline Authors & Field of Study/Objective & Results \\
\hline $\begin{array}{l}\text { Preeth } \\
(2014)\end{array}$ & $\begin{array}{l}\text { This study aimed at exploring the re- } \\
\text { lationship in business institutions be- } \\
\text { tween emotional intelligence and both } \\
\text { marketing effectiveness and leadership } \\
\text { on one hand, and employee perfor- } \\
\text { mance on the other. }\end{array}$ & $\begin{array}{l}\text { The results showed that emotional intelligence has positive } \\
\text { correlations with all the previously mentioned elements, } \\
\text { which is reflected in growth rates and sales increases. The } \\
\text { study also concluded that there is no evidence or consensus } \\
\text { between researchers on whether emotional intelligence is } \\
\text { an inherited or an acquired skill. }\end{array}$ \\
\hline $\begin{array}{l}\text { Paig } \\
(2012)\end{array}$ & $\begin{array}{l}\text { The research focused on the ability of } \\
\text { pharmaceutical companies to exten- } \\
\text { sively promote and sell their products } \\
\text { in various markets and maintain market } \\
\text { position and customers' trust. }\end{array}$ & $\begin{array}{l}\text { The study concluded that the ability of marketing managers } \\
\text { and salespersons to market their products in the country of } \\
\text { origin and in other countries is linked to employees' emotional } \\
\text { intelligence, which was proved to be as important as their pro- } \\
\text { fessional knowledge, market intelligence and marketing skills. }\end{array}$ \\
\hline $\begin{array}{l}\text { Staton et } \\
\text { al., (2012) }\end{array}$ & $\begin{array}{l}\text { This study examined how the custom- } \\
\text { er's loyalty to the product is affected by } \\
\text { individual differences of consumers and } \\
\text { the marketers' use of either sympathy or } \\
\text { boasting and pride in their promotional } \\
\text { campaigns. }\end{array}$ & $\begin{array}{l}\text { It was concluded that advertising and promotional activities } \\
\text { that draw on sympathy and appeal only attract vulnerable } \\
\text { customers who view themselves as weak and lack self-confi- } \\
\text { dence; whereas using promotional and advertising activities } \\
\text { that draw upon pride and dignity attracts strong, self-confi- } \\
\text { dent people who view themselves as different and unique. }\end{array}$ \\
\hline
\end{tabular}

\section{Market Spread}

\begin{tabular}{|c|c|c|}
\hline Authors & Field of Study/Objective & Results \\
\hline $\begin{array}{l}\text { Jean and } \\
\text { Charles } \\
\text { Chebat } \\
\text { (2015) }\end{array}$ & $\begin{array}{l}\text { The purpose of this study was to } \\
\text { propose a comprehensive model } \\
\text { of the direct interactive effects en- } \\
\text { suing from awareness and emo- } \\
\text { tions on consumer loyalty. }\end{array}$ & $\begin{array}{l}\text { Researchers proposed a cognitive model featuring all the dif- } \\
\text { ferent components of the study that contributes to building } \\
\text { consumer loyalty. Results assured that there are some main } \\
\text { emotional variables such as: pleasure, excitement and comfort } \\
\text { which have a dynamic role in affecting consumer loyalty. }\end{array}$ \\
\hline $\begin{array}{c}\text { Cronin } \\
\text { and Taylor } \\
\text { (1992) }\end{array}$ & $\begin{array}{l}\text { The study explored the relation- } \\
\text { ship between psychological and } \\
\text { emotional variables such as: plea- } \\
\text { sure, excitement and comfort and } \\
\text { their effect on customer loyalty. }\end{array}$ & $\begin{array}{l}\text { The study concluded that the emotional variables of consumer } \\
\text { behavior are the most important aspects and are also frequent- } \\
\text { ly ignored by some managers despite their importance in raising } \\
\text { customer loyalty and satisfaction. The study presented a compre- } \\
\text { hensive cognitive model for customer loyalty towards the ser- } \\
\text { vices that they receive depending on certain emotional variable. }\end{array}$ \\
\hline
\end{tabular}

\section{Studies Related with More Than One of the Studying Variables}

\begin{tabular}{|c|c|c|}
\hline Authors & Field of Study/Objective & Results \\
\hline $\begin{array}{c}\text { Siphiwe et al. } \\
\text { (2014) }\end{array}$ & $\begin{array}{l}\text { This study presents a deep and comprehen- } \\
\text { sive understanding of the impact of emo- } \\
\text { tional intelligence on both consumer loyal- } \\
\text { ty to a product or a brand. It also explores } \\
\text { how public universities could employ emo- } \\
\text { tional intelligence in their management } \\
\text { styles to promote their survival and conti- } \\
\text { nuity and maintain their statuses and po- } \\
\text { sitions in light of the ongoing competition } \\
\text { between the public and private sectors. }\end{array}$ & $\begin{array}{l}\text { Results showed that } 79 \% \text { of the research sample } \\
\text { (senior management, faculty staff, administrators, } \\
\text { students) all confirmed that incorporating emotional } \\
\text { intelligence in the marketing process will help create } \\
\text { a positive relationship among recipients of university } \\
\text { services. In conclusion, the study recommended in- } \\
\text { corporating elements of emotional intelligence sub- } \\
\text { stantially in education and using it as a strategic tool } \\
\text { to gain a competitive edge in order to guarantee the } \\
\text { continuation and leadership of university institutions. }\end{array}$ \\
\hline
\end{tabular}




\begin{tabular}{|c|c|c|}
\hline Authors & Field of Study/Objective & Results \\
\hline $\begin{array}{l}\text { Tavakoli } \\
\text { (2014) }\end{array}$ & $\begin{array}{l}\text { This study explored the role of emotional } \\
\text { intelligence in the spread of the product in } \\
\text { more than one market. }\end{array}$ & $\begin{array}{l}\text { By studying small and medium-sized industrial } \\
\text { enterprises, the study concluded that having em- } \\
\text { ployees who possess emotional intelligence has a } \\
\text { vivid role in the success, spread and continuation of } \\
\text { these organizations and their survival in many dif- } \\
\text { ferent markets. }\end{array}$ \\
\hline $\begin{array}{l}\text { Jung-Hyun et } \\
\text { al. (2012) }\end{array}$ & $\begin{array}{l}\text { Researchers focused on studying the rela- } \\
\text { tionship between emotional intelligence, } \\
\text { new corporate services and levels of em- } \\
\text { ployee loyalty. }\end{array}$ & $\begin{array}{l}\text { Results showed that emotional intelligence has a } \\
\text { very positive and strong effect in renovating cor- } \\
\text { porate services and promoting employee loyalty. } \\
\text { Moreover, there is a strong relationship between } \\
\text { organizational loyalty and continuously updating } \\
\text { services provided to the customers. Organization- } \\
\text { al loyalty mediates the relationship between emo- } \\
\text { tional intelligence levels of decision makers and the } \\
\text { level of corporate services and updated marketing } \\
\text { activities. }\end{array}$ \\
\hline $\begin{array}{c}\text { Zahra and } \\
\text { Hassan (2012) }\end{array}$ & $\begin{array}{l}\text { The researchers studied the relationship } \\
\text { between emotional intelligence and the } \\
\text { attitudes of a given organization in iden- } \\
\text { tifying the needs of its current and target } \\
\text { customers. }\end{array}$ & $\begin{array}{l}\text { The basic results confirmed that there is a strong } \\
\text { relationship between emotional intelligence of } \\
\text { managers and their directives towards their target } \\
\text { markets and clients; the more leaders and manag- } \\
\text { ers of decision makers are able to manage them- } \\
\text { selves, others, and relations, the positive the ability } \\
\text { of the organization become to identify customers' } \\
\text { needs and the ability to cope with their aspirations, } \\
\text { changing tastes which reflect on putting a compet- } \\
\text { itive strategy that guarantees the continuity of the } \\
\text { organization and existence in the market. }\end{array}$ \\
\hline $\begin{array}{l}\text { Noura et al. } \\
\text { (2011) }\end{array}$ & $\begin{array}{l}\text { This study was applied to banking to ex- } \\
\text { plore the impact of emotional intelligence } \\
\text { on marketing operations effectiveness. }\end{array}$ & $\begin{array}{l}\text { The research concluded that the leaders in banking } \\
\text { institutions who possess high levels of emotional } \\
\text { intelligence have the ability to run highly effective } \\
\text { marketing operations and activities compared to } \\
\text { their others. }\end{array}$ \\
\hline Tareq (2010) & $\begin{array}{l}\text { The study explored the impact of emo- } \\
\text { tional intelligence of leaders on their cre- } \\
\text { ative and innovative abilities in the field of } \\
\text { marketing. }\end{array}$ & $\begin{array}{l}\text { Results showed that emotional intelligence has a } \\
\text { strong effect on self-awareness, personal control } \\
\text { over motives and emotions, social skills and cre- } \\
\text { ativity in marketing with some variance in demo- } \\
\text { graphic elements like: gender, age, education, social } \\
\text { status and expertise. }\end{array}$ \\
\hline $\begin{array}{l}\text { Auhiauz et al. } \\
\qquad(2009)\end{array}$ & $\begin{array}{l}\text { This research focused on banking institu- } \\
\text { tions in Nigeria in order to study the effect } \\
\text { of emotional intelligence variables and } \\
\text { marketing effectiveness on the success of } \\
\text { these enterprises. }\end{array}$ & $\begin{array}{l}\text { Results asserted that the success of leaders to man- } \\
\text { age and guide the emotions of their teams depend- } \\
\text { ed intensively on the leaders' own emotional in- } \\
\text { telligence. The higher their emotional intelligence, } \\
\text { the higher market effectiveness they have in their } \\
\text { organizations. }\end{array}$ \\
\hline
\end{tabular}




\begin{tabular}{|c|c|c|}
\hline Authors & Field of Study/Objective & Results \\
\hline $\begin{array}{l}\text { Kumar et al. } \\
\qquad(2003) \text {; } \\
\text { Jones and Tay- } \\
\text { lor (2007) }\end{array}$ & $\begin{array}{l}\text { The two studies focused on exploring the } \\
\text { strength of the relationships based on } \\
\text { emotions and those based on awareness } \\
\text { with products and their brands. }\end{array}$ & $\begin{array}{l}\text { The results of both studies agreed that a relationship } \\
\text { based on emotion - not cognition - towards the product } \\
\text { and its brand is characterized by a great deal of flexibil- } \\
\text { ity. This sometimes allows the consumers to overlook } \\
\text { the high price of their desired product, and avoid look- } \\
\text { ing to competing brands, which means the consumer } \\
\text { reaches a high degree of loyalty to the product. }\end{array}$ \\
\hline Bagozzi (1997) & $\begin{array}{l}\text { The study examined the important role of } \\
\text { marketers who possess higher emotional } \\
\text { intelligence in generating combinations of } \\
\text { marketing strategies and tools that meet } \\
\text { the goals of both the organization and its } \\
\text { clients. }\end{array}$ & $\begin{array}{l}\text { The study stressed the importance of measuring } \\
\text { levels of emotional intelligence when selecting sale } \\
\text { representatives in order to predict their capabilities } \\
\text { in influencing clients, understanding their individu- } \\
\text { al emotions, and embracing their reactions - which } \\
\text { can be seen as the most important element of emo- } \\
\text { tional intelligence. }\end{array}$ \\
\hline $\begin{array}{l}\text { Berry and } \\
\text { Parasuraman } \\
\text { (1996) }\end{array}$ & $\begin{array}{l}\text { The study identified the psychological } \\
\text { mechanisms of customers towards a giv- } \\
\text { en type of service which reflects the level } \\
\text { of loyalty to the brand. }\end{array}$ & $\begin{array}{l}\text { The study concluded that the consumer's evalua- } \\
\text { tion level of a service has a positive correlation with } \\
\text { their level of loyalty to the product/brand and their } \\
\text { pleading in its favor. }\end{array}$ \\
\hline $\begin{array}{l}\text { Hoch and } \\
\text { Deighton } \\
\text { (1989) }\end{array}$ & $\begin{array}{l}\text { Researchers focused on studying the im- } \\
\text { pact of individual's self-management and } \\
\text { self-awareness, as two variables of emo- } \\
\text { tional intelligence, on levels of loyalty to } \\
\text { the product. }\end{array}$ & $\begin{array}{l}\text { The study concluded that the strong person is in- } \\
\text { clined to feel loyalty and pride in the most popular } \\
\text { brands worldwide as a result of what these compa- } \\
\text { nies of employing marketing strategies that depend } \\
\text { on pride, loyalty and strength. Vulnerable individu- } \\
\text { als on the other hand achieve product loyalty as a } \\
\text { response to marketing strategies that employ sym- } \\
\text { pathy and appeal. }\end{array}$ \\
\hline
\end{tabular}

\section{Hypotheses}

- $\quad \mathbf{H}_{1}$ : There is no relationship between Emotional Intelligence variables and Marketing Effectiveness variables.

- $\quad \mathbf{H}_{2}$ : Emotional Intelligence variables have no effect on Market Spread variables.

- $\quad \mathbf{H}_{3}$ : Marketing Effectiveness variables have no effect on Market Spread variables

The following figure demonstrates the three hypotheses of the study:

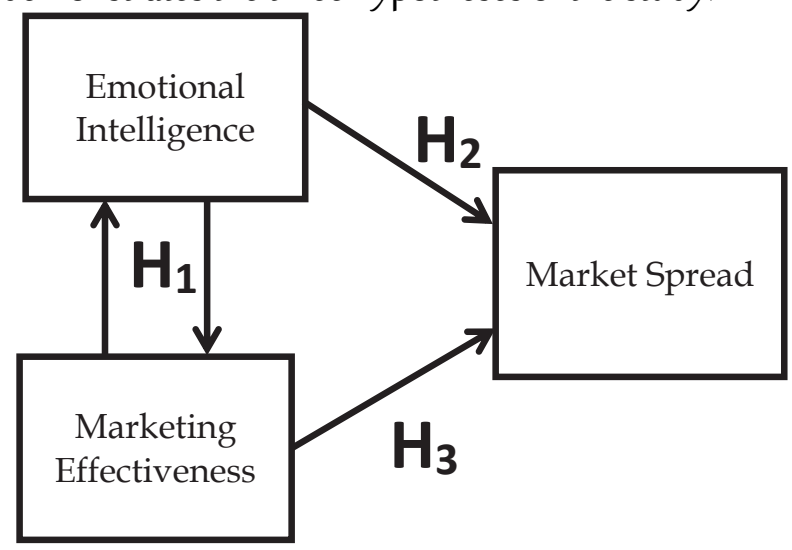

Figure 1: Demonstration of $\mathrm{H}_{1^{\prime}} \mathrm{H}_{2^{\prime}}$ and $\mathrm{H}_{3}$ 


\section{Research Sample and its Characteristics}

The researcher has used multi-stage random sampling in this study. In phase 1, an inventory was made of all the executive managers working in multi-national companies in different industrial sectors in Egypt $(N=234)$. In phase 2 , the research sample was calculated using percentage $(n=158)$. By redistributing the research sample using the proportional allocation (Table 5A), the number of managers was distributed as follows:

- Chemical sector: 26 managers, representing 17.6\% of the total sample,

- Metallurgical sector, 35 managers representing $23.7 \%$ of the total sample,

- Food sector: 38 managers representing $25.7 \%$ of the total sample,

- Engineering sector: 16 managers representing 11\% of the total sample,

- Construction materials sector: 10 managers representing 7\% of the total sample,

- Pharmaceutical sector: 13 managers representing 9\% of the total sample,

- Textile sector: 10 managers representing $7 \%$ of the total sample.

One important characteristic of the research sample is that most of managers were males (87.2\%) at the age range of $(40-<50)$ which represents $34 \%$ of the sample. Most managers were either holders of Bachelor Degree ( $57.4 \%$ of the sample) or Master's Degree (37.2\% of the sample). In addition, $71 \%$ of the sample earns more than L.E. 10,000 (table 6A).

\section{Research Methodology and Data Collection}

To ascertain the extent of validity and reliability of the research tool, the researcher conducted an exploratory study on a sample of "30 cases-pilot study" sampling units (Executive Managers). The research used some statistical tools, such as Inter-Consistency which is based on "Simple Linear Pearson Correlation Coefficient" and Factor Loading in order to make sure of the degree of validity of the elements in different variables and variables that are included in the research tool. This is in addition to using Cronbach's Alpha Coefficient in order to identify the degree of reliability across all research tool variables. The following are the results of the validity and reliability of the research tool:

\section{Results of Testing the Validity and Reliability of Emotional Intelligence Variables}

The results mentioned in Table $1 \mathrm{~A}$ confirmed that all validity results across all elements of the four variables of Emotional intelligence are of significance level $=0.01$. In addition, all of these elements were positively correlated and very strong. The Research also emphasized the factor loading values at the level of all elements in the different variables as they have achieved the standard (0.50+). As for the outcome of the reliability, the Cronbach's Alpha Coefficient has ranged between $(\alpha=0.796-0.884)$, which reflects that it has achieved a high degree of reliability.

\section{Results of Testing the Validity and Reliability of Marketing Effectiveness Variables}

The results mentioned in Table 2A confirmed that all validity results across all elements of the four variables of marketing effectiveness using simple correlation coefficients are highly significant at 0.01 level 
of significance. In addition, all of these values of Pearson Correlation Coefficient for all elements were positive and very strong. The Research also emphasized the factor loading values at the level of all elements in the different variables as they have achieved the standard $(0.50+)$. As for the outcome of the reliability, the Cronbach's Alpha Coefficient has ranged between $(\alpha=0.637-0.875)$, which reflects that it has achieved a high degree of reliability.

\section{Results of Testing the Validity and Reliability of Market Spread Variables}

The results mentioned in Table 3A confirmed that all validity results for all elements of the three variables of market spread are highly significant. In addition, the correlation coefficients for all of these elements were positive and very strong. The results also clarify the value of the factor loading for all elements in the different variables as they have achieved the standard (0.50+). As for the outcome of the reliability, the Cronbach's Alpha Coefficient has ranged between $(\alpha=0.827-0.861)$, which reflects that it has achieved a high degree of reliability.

From the previous results in the tables, the researcher can use all of the items of different variables in order to measure the variables and use them to achieve the research objective.

\section{Exploring Certain Inter-relationships between Variables Relationships among Variables of Emotional Intelligence}

It is noted that in Table 7A, there are some inter-relationships between each and all the variables (independent variables), which in turn reflects the results of the Multiple Linear Regression Analysis (MLRA) that assumes the independency of these variables; thus, this result should be considered during the assessment of Regression Analysis (RA) results, despite the fact that these relationships have limited strengths; except for the result of the relationship between Social Awareness and Relationship Management that has "medium value".

\section{Relationships among Variables of Market Effectiveness}

In Table 8A, it is noted that there are inter-relationships between each and all the independent variables. It is worth mentioning that all of these variables were positive and significantly strong at a level of (0.01), which in turn reflects the results of the Multiple Linear Regression Analysis (MLRA) that assumes the independency of these variables. Thus, this result leads to the issue of Multi-Collinearity problem considered during the process of the Regression Analysis Model.

\section{Results of Research Hypotheses Testing}

\section{Results of Research of the First Hypotheses Testing}

$\mathrm{H}_{1}$ : “There are no relationships between Emotional Intelligence variables and Marketing Effectiveness variables".

The following table shows the results for the relationships between Emotional Intelligence variables and Marketing Effectiveness variables using Pearson Simple Linear Correlation Coefficient. 
Table No. (2)

The relationships between Emotional Intelligence variables (E.I.) and Marketing Effectiveness variables (M.E.) using Pearson Correlation Coefficients

\begin{tabular}{|c|c|c|c|c|}
\hline E.I. & & & & \\
\hline M.E. & $x_{1}-11$ & $x_{1}-21$ & $x_{1}-31$ & $x_{1}-4 I$ \\
\hline$x_{2}-1 T$ & $0.344^{* *}$ & $0.684^{* *}$ & -0.102 & 0.104 \\
\hline$x_{2}-2 T$ & $0.598 * *$ & $0.517^{* *}$ & $0.245^{* *}$ & 0.130 \\
\hline $\mathrm{X}_{2}-3 \mathrm{~T}$ & $0.583^{* *}$ & $0.606^{* *}$ & $0.175^{*}$ & $0.231^{* *}$ \\
\hline $\mathrm{X}_{2}-4 \mathrm{~T}$ & $0.545^{* *}$ & $0.735^{* *}$ & 0.151 & $0.215^{*}$ \\
\hline$X_{2-5 T}$ & $0.343^{* *}$ & $0.675^{* *}$ & -0.035 & 0.106 \\
\hline
\end{tabular}

The results mentioned in the above table confirm the existence of relationships between Emotional Intelligence variables and Marketing Effectiveness variables, especially between self-consciousness, self-management and all the variables of Marketing Effectiveness - all of which were significant at a level of 0.01. In addition, some relationships have evolved between social awareness and both integrated marketing efforts and marketing information; as well as relationships between relationship management and both marketing information and strategic orientation. It is worth mentioning that all relationships were proportional.

With respect to the first two variables of Emotional Intelligence related to the individual (manager) himself, a manager who has independency and self-control resulting from Emotional Intelligence, he/she has the ability to achieve all the variables of Marketing Effectiveness. The Manager in this case is the one who sets the plans and strategic direction of an organization and is concerned with marketing information and operational efficiency. Besides, he/she is also concerned with the integration of marketing efforts that are directed to serve and meet consumer expectations.

As for social awareness, which is one of the two variables, it reflects the relationship between an individual and a group. Results have showed that there is a positive relationship between social awareness and all variables of Marketing Effectiveness related to the group, such as integrated marketing efforts and marketing information - which cannot be achieved by an individual (manager) alone without cooperation with others in the group and his/her realization of Emotional Intelligence towards the group.

As for the second dimension of the relationship between the individual and the group, results showed a positive relationship between relationship management and both marketing information and strategic direction of an organization. This positive relationship can only be achieved through individual's intelligence and his/her relationships with the activities organized by other departments or individuals inside the organization.

These results correspond to previous studies, such as Preeth (2014) which confirmed that there is a relationship between Emotional Intelligence and Marketing Effectiveness variables and a relationship between leadership and the level of individual performance of an employee within an organization. The researcher also stressed that there is no clear evidence on whether Emotional Intelligence is an inherited or acquired trait. Moreover, the study of Auhiauz et al. (2009) confirmed the existence of a strong relationship between Emotional Intelligence and Marketing Effectiveness, and thus the main result is that Emotional Intelligence leads to Marketing Effectiveness. 
Finally and from the previous presentation of first hypothesis test results, we can reject the validity of this hypothesis.

\section{Results of Research of the Second Hypotheses Testing}

$\mathrm{H}_{2}$ “Emotional Intelligence variables have no effect on Market Spread variables in an organization".

The following table shows the result of the Regression Analysis for the Emotional Intelligence variables (Independent variables) on Market Spread (Dependent variables).

Table No. (3)

Regression Analysis of Emotional Intelligence variables' impact on Market Spread variables

\begin{tabular}{|c|c|c|}
\hline $\begin{array}{l}\text { Dependent Vari- } \\
\text { able }\end{array}$ & $\begin{array}{c}\text { Estimating } \\
\text { Parameter Testing } \\
\end{array}$ & Estimating a Model and its Tests \\
\hline \multirow{4}{*}{ Loyalty } & Unstandardized & $\mathrm{Yt}-1=2.402+0.189 \mathrm{X}_{1}-1 \mathrm{~T}+0.323 \mathrm{X}_{1}-2 \mathrm{~T}$ \\
\hline & Standardized & 0.229 \\
\hline & T-test Value & $* *(6.214) * * *(2.991) * * *(10.902)$ \\
\hline & Tests for the Model & $\begin{array}{c}\text { F-ratio }=47.300 * * *, \text { d.f. }=(2,145), \operatorname{Sig}=0.000 \\
\left.\text { Sig }=\text { at } 0.01), R^{2}=39.5 \%, \text { S.E. }=0.381\right)\end{array}$ \\
\hline \multirow{4}{*}{$\begin{array}{l}\text { Marketing } \\
\text { Positioning }\end{array}$} & Unstandardized & $\mathrm{Yt}_{\mathrm{t}-2}=0.624+0.217 \mathrm{X}_{1}-1 \mathrm{~T}+0.313 \mathrm{X}_{1}-2 \mathrm{~T}+0.675 \mathrm{X}_{1}-4 \mathrm{~T}$ \\
\hline & Standardized & $\begin{array}{lll}0.437 & 0.382 & 0.217\end{array}$ \\
\hline & T-test Value & $* * *(6.937) * * *(5.438) * * *(2.917)(1.477)$ \\
\hline & Tests for the Model & $\begin{array}{c}\text { F-ratio }=53.569 * * *, \text { d.f. }=(3,144), \operatorname{Sig}=0.000 \\
\left.\text { Sig }=\text { at } 0.01), R^{2}=52.7 \%, \text { S.E. }=0.407\right)\end{array}$ \\
\hline \multirow{4}{*}{ Mental Image } & Unstandardized & $\mathrm{Yt}-3=1.089+0.549 \mathrm{X}_{1}-2 \mathrm{~T}+0.197 \mathrm{X}_{1}-4 \mathrm{~T}$ \\
\hline & Standardized & 0.118 \\
\hline & T-test Value & $*(1.833) * * *(9.636) * *(2.128)$ \\
\hline & Tests for the Model & $\begin{aligned} \text { F-ratio } & =47.666^{* * *}, \text { d.f. }=(2,145), \text { Sig }=0.000 \\
\text { Sig } & \left.=\text { at } 0.01), R^{2}=39.7 \%, \text { S.E. }=0.493\right)\end{aligned}$ \\
\hline Denotes F. Ra & $\mathrm{d}$ T-Test are significant at $\mathrm{C}$ & ficance. \\
\hline $\begin{array}{l}\text { Denotes T-test i } \\
\text { Denotes T-test } \mathrm{i}\end{array}$ & $\begin{array}{l}\text { significant at } 0.05 \text { level of sig } \\
\text { significant at } 0.1 \text { level of sig }\end{array}$ & \\
\hline
\end{tabular}

\section{Results of the Regression Analysis}

1- Results of Market Positioning: The value of " $F$ " (calculated $F=53.569$ ) confirms its statistical significance at 0.01 level of significance with degree of freedom $(3,144)$. The results also confirmed that the most important variables and variables of Emotional Intelligence and their impact on Market Positioning were as follows:

- Relationship Management $\left(X_{1}-4 t\right)$

- Self-management $\left(\mathrm{X}_{1}-2 \mathrm{t}\right)$

- Self-awareness $\left(\mathrm{X}_{1}-1 \mathrm{t}\right)$ 
According to the results stated by the Standardized Coefficients, the previous three variables explain the changes of Market Positioning with about 52.7\%. Moreover, it is worth mentioning that the impact of these variables was positive. Also, results have showed that the impact of Relationship Management, Self-management and Self-awareness on Loyalty was positive, which is consistent with the scientific theory of Marketing Science.

2- Results of Brand Image: The value of " $F$ " test (calculated F=47.666) confirms its statistical significance at 0.01 level of significance with degree of freedom $(2,145)$. The results also confirmed that the most important variables and variables of Emotional Intelligence and their impact on Brand Image were as follows:

- Self-management $\left(\mathrm{X}_{1}-2 \mathrm{t}\right)$

- Relationship Management $\left(X_{1}-4 t\right)$

According to the results stated by the Standardized Coefficients, the previous two variables explain the changes of Brand Image with about 39.7\%. Moreover, it is worth mentioning that the impact of these variables was positive as it affected the Brand Image.

3- Results of Loyalty. The value of " $F$ " test (calculated $F=47.300$ ) confirms its statistical significance at the level of moral varying $(2,145)$. The results also confirmed that the most important variables of Emotional Intelligence and their impact on Loyalty were as follows:

- Self-management $\left(\mathrm{X}_{1}-2 \mathrm{t}\right)$

- Self-awareness $\left(\mathrm{X}_{1}-1 \mathrm{t}\right)$

According to the results stated by the Standardized Coefficients, the previous two variables explain the changes of Market Positioning with about 39.5\%. Moreover, it is worth mentioning that the impact of these variables was positive as it affected Loyalty.

\section{This Result Corresponds to the Conclusions of Each of the Following Studies}

- Tavakoli (2014) study that has confirmed the importance and role of Emotional Intelligence in the spread of a product in more than one market, and concluded that the availability of Emotional Intelligence variables has an important and influential role in the success, spread and survival of companies in different markets.

- Studies of Jones and Taylor (2007) and Kumar et al. (2003) which indicated that relationships based on emotion - not cognition - towards the product and its brand are characterized by a great deal of flexibility. This sometimes allows the consumers to overlook the high price of his/her desired product, and avoid looking to competing brands, which means the consumer reaches a high degree of loyalty to the product.

- Zahra and Hasan (2012) study, where the primary result has confirmed that there is a strong relationship between the Emotional Intelligence of managers and their attitudes toward their markets and target customers; whereas the study has confirmed that the more an organization has leaders and marketing managers or other decision makers who have the ability to manage themselves and others as well as good at Relationship Management, the more it has a positive and clear im- 
pact on the organization's ability to identify and know the needs of customers, which in turn will be reflected on developing a competitive strategy to ensure the continuation of that organization and its survival in the market. This was confirmed by Keller (2009) with a case study of Coca-Cola Company, which is considered as one of the most important companies that has trained its leaders on Emotional Intelligence as it is a widespread global company.

From the previous presentation of second hypothesis test results, we can reject the validity of this hypothesis.

\section{Studying the Effect of Marketing Effectiveness Variables on the Variables of Market Spread}

$\mathbf{H}_{3}$ "Marketing Effectiveness variables have no effect on Market Spread variables of an organization".

The following table shows the result of the Regression Analysis for Marketing Effectiveness Independent variables on Market Spread (Dependent variables).

\section{Table No. (4)}

Regression Analysis for Marketing Effectiveness effect on Market Spread variables.

\begin{tabular}{|c|c|c|}
\hline Dependent Variable & $\begin{array}{c}\text { Estimating Parameter } \\
\text { Testing }\end{array}$ & Estimating a Model and its Tests \\
\hline \multirow{4}{*}{ Loyalty } & Unstandardized & $Y t-1=1.670+0.506 X_{2}-3 t+0.434 X_{2}-5 t-0.244 X_{2}-4 t$ \\
\hline & Standardized & $\begin{array}{lll}0.631 & 0.568 & -0.334\end{array}$ \\
\hline & T-test Value & $\left(11.326^{* *}\right)\left(6.265^{* *}\right)\left(6.094^{* *}\right)\left(-2.768^{* *}\right)$ \\
\hline & Tests for the Model & $\begin{array}{c}\text { F-ratio }=115.619 * *, \text { d.f. }=(3,144), \text { Sig }=0.000 \\
\quad(S i g=\text { at } 0.01), R^{2}=70.7 \%, \text { S.E. }=0.266\end{array}$ \\
\hline \multirow{4}{*}{$\begin{array}{l}\text { Marketing Position- } \\
\text { ing }\end{array}$} & Unstandardized & $\mathrm{Yt}-2=1.692+0.904 \mathrm{X}_{2}-3 \mathrm{t}-0.260 \mathrm{X}_{2}-2 \mathrm{t}$ \\
\hline & Standardized & $0.936-0.273$ \\
\hline & T-test Value & $\left(7.701^{* *}\right)\left(10.685^{* *}\right)\left(-3.114^{* *}\right)$ \\
\hline & Tests for the Model & $\begin{array}{c}\text { F-ratio }=90.347^{* *}, \text { d.f. }=(2,145), \text { Sig }=0.000 \\
\quad(S i g=\text { at } 0.01), R^{2}=55.5 \%, \text { S.E. }=0.393\end{array}$ \\
\hline \multirow{4}{*}{ Mental Image } & Unstandardized & $Y t-3=0.989+0.274 X_{2}-3 t-0.516 X_{2}-5 t$ \\
\hline & Standardized & $0.263-0.520$ \\
\hline & T-test Value & $\left(4.280^{* *}\right)\left(2.807^{* *}\right)\left(-5.537^{* *}\right)$ \\
\hline & Tests for the Model & $\begin{array}{c}\text { F-ratio }=92.632 * *, \text { d.f. }=(2,145), \text { Sig }=0.000 \\
(S i g=\text { at } 0.01), R^{2}=56.1 \%, \text { S.E. }=0.421\end{array}$ \\
\hline
\end{tabular}

From the above table, the results confirmed the existence and effect of Marketing Effectiveness variables on Market Spread variables.

These results will be presented in a Regression Model estimate of Marketing Effectiveness variables for each variable of market spread as follows:

1- Results of Loyalty: The value of " $F$ " test (calculated $F=11.619)$ confirms its statistical significance at (0.01) level of significance with degree of freedom $(3,144)$. The results also confirmed that the most 
important variables of Marketing Effectiveness and their impact on Loyalty were as follows:

- Gathering Adequate Marketing Information $\left(X_{2}-3 t\right)$

Positive effect

- Operational Efficiency $\left(\mathrm{X}_{2}-5 \mathrm{t}\right)$

Positive effect

- Existence of Strategic Orientation $\left(X_{2}-4 t\right)$

Negative effect

According to the results of Standardized Coefficients, the previous three variables explain the changes of Loyalty with about $71.0 \%$. Also, it is noted that the impact of both Marketing Information and Operational Efficiency on Loyalty has been fully consistent with the scientific theory of Marketing Science (positive effect). On the contrary, the impact of Strategic Orientation on Loyalty has negative effect. This may be because an organization devotes all material and human resources to a product in a particular market until the consumer size and segment expand within this market, and ensure that current consumers have a high degree of loyalty to that product. Then, the organization starts to devote its resources and strategic plans to another market, thus the relation appears negative as included in the results.

2- Results of Brand image: The value of " $F$ " test (calculated $F=92.632$ ) confirms the statistical significance at (0.01) level of significance with degree of freedom $(2,145)$. The results confirmed that the most important variables of Marketing Effectiveness have a great impact on Brand Image.

- Operational Efficiency

$\left(X_{2}-5 t\right)$

- Gathering Adequate Marketing Information

$\left(X_{2}-3 t\right)$

According to the results stated by Standardized Coefficients, the previous two variables explain the changes in the rate of Brand Image with about 56.1\%. It is worth mentioning that the impact of each of the two previous variables was proportional. Also, it is noted that the impact of both Marketing Information and Operational Efficiency on Brand Image have been fully consistent with the scientific theory of Marketing Science (positive effect).

3- Results of Market Positioning: The value of " $F$ " test (calculated $F=90.347$ ) confirms the statistical significance at (0.01) level of significance with degree of freedom $(2,145)$. The results also confirmed that the most important variables of Marketing Effectiveness have a great impact on Market Positioning.

- Gathering Adequate Marketing Information

$\left(X_{2}-3 t\right)$ Positive effect

- Integration and Control of Major Marketing Functions

$\left(X_{2}-2 t\right)$ Negative effect

According to the results stated by the Standardized Coefficients, the previous two variables explain the changes of Market Positioning by 55.5\%. Also, it is noted that the impact of Marketing Information on Market Positioning has been fully consistent with the scientific theory of Marketing Science (positive effect). On the contrary, the impact of Integrated Marketing Efforts on Market Positioning has a negative effect. This may be because the adequate using of marketing efforts may result in lower market positioning of a product, which in turn will lead to an unclear image of the product in consumer markets. On the other side, the over limitation of market positioning may lead to an increase the level of consumers' aspirations and expectations of the product, considering it will achieve more than expected.

From the previous presentation of the third hypothesis test results, we can reject the validity of this hypothesis. 
Table No. (5)

A statement of the research variables encoded according to their inserting by the computer

\begin{tabular}{lcc}
\hline Serial & Variables Study & Encoding Variables \\
\hline $1-$ & Emotional intelligence & \\
& $-\quad$ Self-awareness. & X1_1t \\
& $-\quad$ Self-control. & X1_2t \\
& $-\quad$ Social awareness. & X1_3t \\
& $-\quad$ Relationship management. & X1_4t \\
\hline $2-$ & The Effectiveness of Marketing & \\
& $-\quad$ Client philosophy. & X2_1t \\
& $-\quad$ Integration and supervision of key marketing functions. & X2_2t \\
& $-\quad$ Collecting sufficient marketing information. & X2_3t \\
& $-\quad$ Strategic guidance. & X2_4t \\
& $-\quad$ Operational efficiency.. & X2_5t \\
\hline $3-$ & Market Spreading & Yt_1 \\
& $-\quad$ Consumer loyalty. & Yt_2 \\
& $-\quad$ Market position. & Yt_3
\end{tabular}

The Results Of The Three Models Related To Market Spread as Follows:

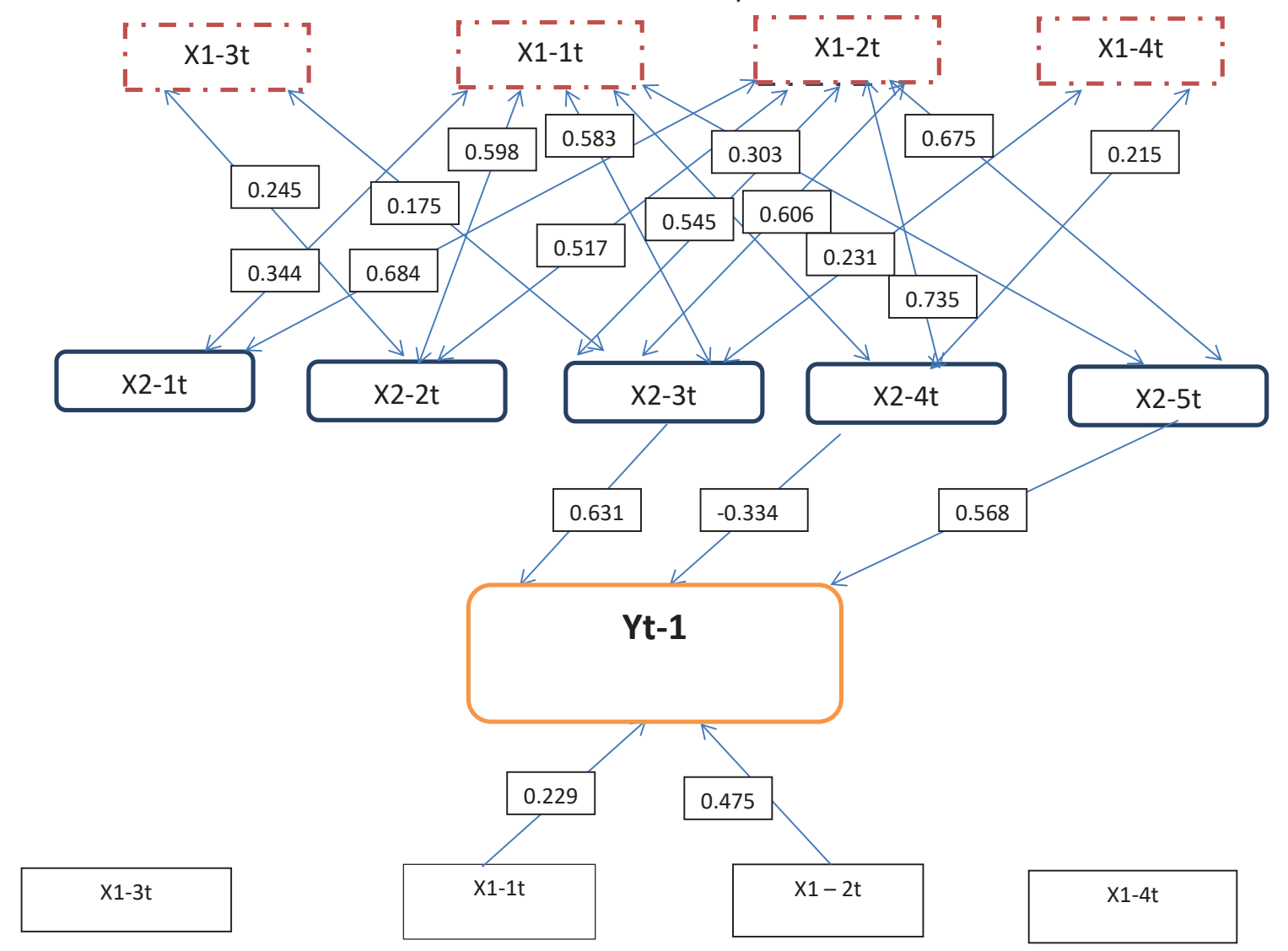

Model (1): Results of the first model of the impact of emotional intelligence variables and the effectiveness of marketing on consumer loyalty 


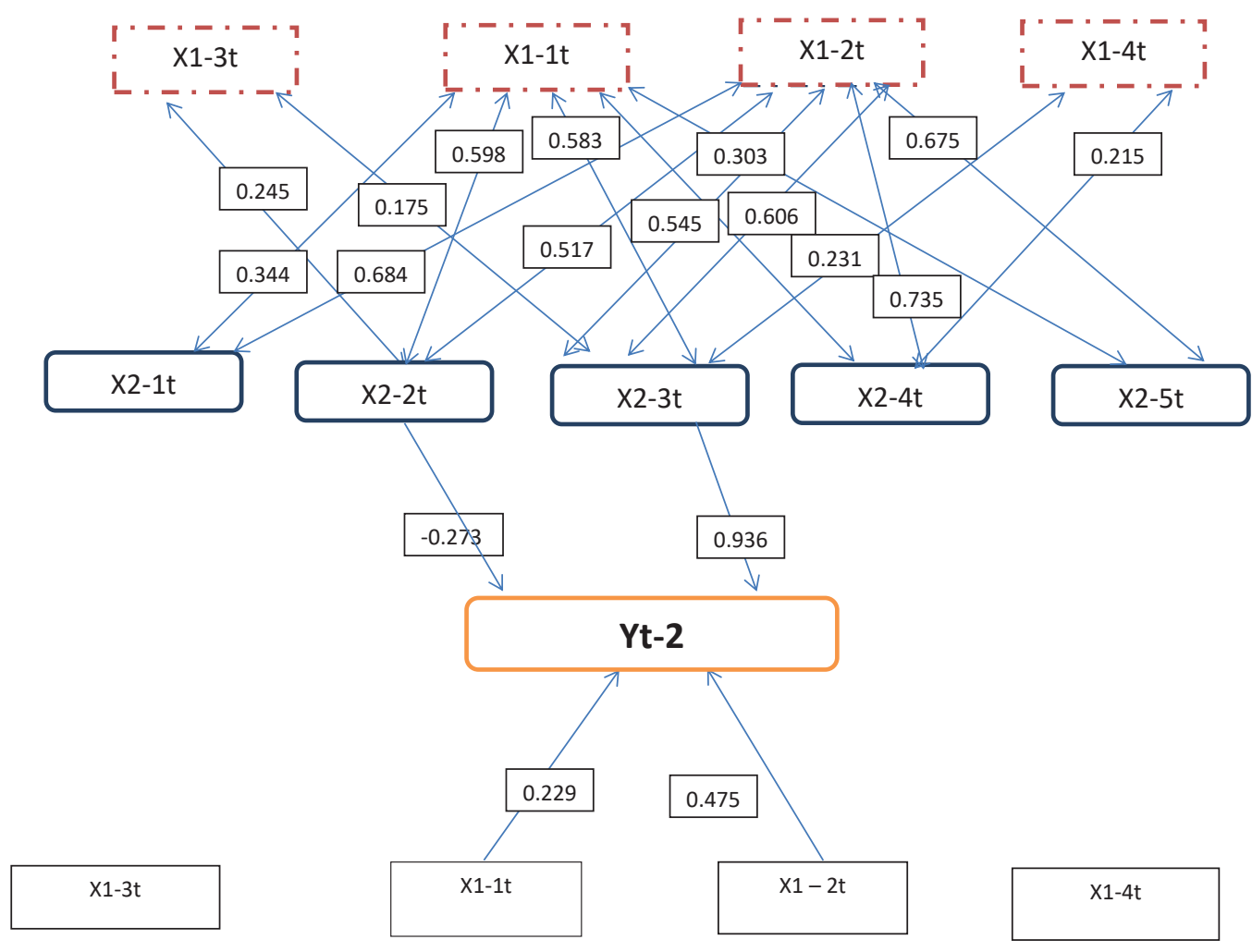

Model (2): Results of the second model of the effect of emotional intelligence variables and the effectiveness of marketing on the status of the market

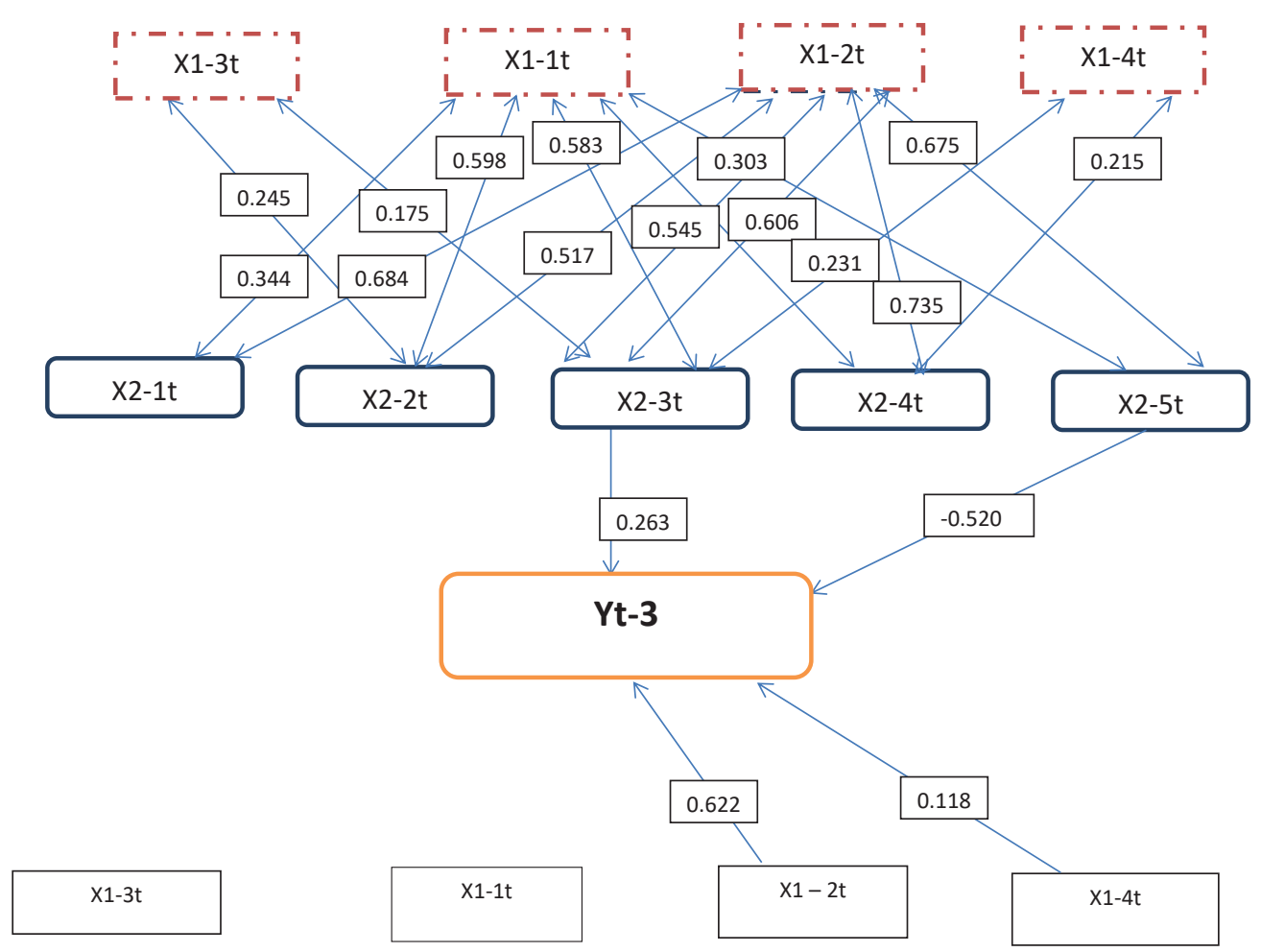

Model (3): Results of the third model of the effect of emotional intelligence variables and marketing effectiveness on mental image 
The results of the three previous models confirmed that there is a strong and powerful effect of both self-control and marketing information on the three market spread variables. The methods of collecting good marketing information through periodic marketing research may provide managers with a lot of information that requires them to quickly respond to sudden Irrational Events, and to face them quickly and wisely. He who would have the ability to manage itself and control itself and manage emotions and motives during the crises facing his organization as well as the ability to adapt quickly rather than turning a blind eye to it, it will reflect positively on his new marketing policy if necessary to change it, which will in turn reflect positively on both the loyalty of the customer to the product, the market position and the upgrading of his mental image.

The results of the three previous models also confirmed:

- There is a strong positive impact of operational efficiency on consumer loyalty.

- There is a strong positive impact of the relationship management on the market position.

- There is a strong inverse impact of operational efficiency and a positive impact of the relationship management on mental image.

As these companies are international companies which its branches spread in multiple countries, including development and advanced countries, it may sometimes occur some shortcomings in the operational aspects and in the ability of the local company's branch to manage its resources and face the sudden changes to which negatively impact on the mental image of the product in that developing country. In spite of consumer loyalty to the same product in many other countries, however, the mental image of the product may vary in some countries because of the lack of production or storage operations, etc. The researcher then sees substituting this lack of interest in management of relations and self-control as well as collecting marketing information to treat deficiencies as soon as they arise and to address them.

The results also showed that the self-awareness variable has a positive impact on both consumer loyalty and market position. Self-awareness is associated with some managerial competencies associated with deep self-understanding of managers, and their ability to cope with their strengths and weaknesses (Goleman's Modified Model, 2001).

Goldman shows that individuals with strong self-awareness, usually characterized by realism and honesty with themselves, and with others, and managers with these characteristics have the ability to face many administrative and marketing difficulties, which is reflected greatly on their practical and professional achievements to achieve all of the loyalty and market position of the product.

The results in Figure 1 confirmed that there is an adverse impact of the strategic orientation on the consumer loyalty of the multinational companies. This may be due to the fact that the development and modernization of the strategic plans in these companies, which depends on innovation and work on introducing new products, may cause the organization to lose the loyalty of some of its current consumers (especially in some developing countries) because of their habituation of the product and consumption in a certain way. Although these developments may gain the organization entry of a new category of customers in different age groups with unusual demographic characteristics, In general, results showed that strategic orientation of companies may conflict with the loyalty of some of the current consumers. 
There is also an adverse impact of the integration and supervision of the main marketing functions on the market position. This may be due to the fact that in the stage of completion of the product for the life cycle and reaching the stage of saturation and aging, the marketing activities are aimed at modifying the existing products and causing the necessary development and innovation such as adding new products or deleting Etc. This may adversely affect the marketing position of the organization as its competitive position varies for a limited period and its revenues decrease as a result of the organization's implementation of its marketing activities. Here the organization tries to cover the costs of its various activities and work on its integration to achieve the function of marketing management which is providing the organization with profits.

As for social awareness, the results showed that this variable has no impact on the three variables of market spreading (consumer loyalty, market position, and mental image), since this variable is considered to be a social variable, as Goldman said 2001. The nature of this variable is primarily social and has to do with the leader/manager who can predict what is going on in the minds of those directly involved. It also has the ability to follow the satisfaction of the agent and the authorized distributor, as well as the final consumer of the product, not only from the periodic reports to follow up.

The results also confirm that there is no impact of the client's philosophy variable on each of the three market spread variables (consumer loyalty, market position, mental image). The presence of international companies in some markets which is different culturally and socially, makes it design a marketing policy that may vary from country to another, because of the difference in purchasing power and methods of control and supervision and storage of their products, this may have negative impacts on some customers, we find them despite their loyalty to the product and its good position and a mental image, and because of the policy of the company from one market to another, they do not consume the same product at their move from a country to another due to the customer knows and awareness of the low quality of the product or belief that there are two levels of the product.

\section{Discussion}

From the above, we find that the effect of the variables of Marketing Effectiveness on the spread of the market emerged clear and strong relationships of the multiple variables of emotional intelligence. The effect of the relationship was clearly evident between the variables of Emotional Intelligence and Market Spread. So the self-management and self-awareness of managers who have such characteristics have a great ability to manage social relations with high social awareness. This reflects positively on their thinking and style in their relationships with individuals, society and outside institutions as well as on the status and position of their products and marketing services in the market. They are also being helped by gathering the marketing information, which came in an opposite relationship with the study in line with the market position, so that the information is available with the capabilities and attributes of managers to achieve the market positioning of the product.

On the other hand, we find that the impact of the variables of Marketing Effectiveness has left a strong impact on the Market Spread variables, which has been represented in the Brand Image of the product and not the service. Hence, the efficiency of the remaining processes in the organization and its integration with 
marketing information has a strong and effective role in the participation of managers and organization in drawing a good brand image and a competitive one about the product in the mind of its customers.

Finally, Marketing Effectiveness (marketing information, efficiency of operations) has a strong role in achieving Consumer Loyalty through the marketing intelligence system, efficiency and effectiveness of the marketing process associated with all marketing operations in the organization, where the consumer's loyalty to the product is achieved even when moving from one country to another.

Thus, we conclude that there is a strong relationship between all variables of Emotional Intelligence and the variables of Marketing Effectiveness; while the dimension of Self-awareness and Self-management share achieving all the variables of Marketing Effectiveness with Distant Market Position of Market Spread.

\section{Conclusions}

The effect of Emotional Intelligence represented in Self-awareness and Self-management of executive managers is centralized in their ability to understand their own emotions and the emotions of others, and their ability to identify areas of strength and weakness in themselves and others. This reflects theses managers' success in forming strategies and activities that achieve marketing effectiveness. The results stress the existence of inter-relationship between the four variables of Emotional Intelligence on one hand (self-awareness, self-management, social awareness and relationship management) and marketing effectiveness on the other. To achieve and maintain Consumer Loyalty, Mental Image and the required Positioning, a whole system should be adopted starting from selecting the marketers and managers that highly possess self-awareness and self- management as they are more capable of managing others and harnessing their skills, abilities and knowledge to make better changes. These managers possess a high creative ability that manifests itself in setting achievable goals and challenges. They also have an effective ability to calculate risks which keeps their goals on the achievable side of the game. Consequently, their strategies and marketing efforts are mostly more effective and efficient in opening new global markets and taking advantage of relevant seasonal changes in order to achieve the highest possible level of operational efficiency.

Based on the previous studies such as the study by Jean and Charles Chebat (2015) and Amir and Vahid (2015), we find that the results conform with the findings of available research in that executive managers' ability to introduce advertising and marketing policies depend mainly on their relationship management abilities, which will positively affect how sales representatives cope with the established policies. The more these advertisements are based on pleasure, excitement and comfort, the more consumer loyalty there is to the product; even if products move from one market to another and despite variations in product quality when manufactured in developing countries. Some global companies choose to manufacture or assemble certain products in a developing host country to raise production output. And since the level of quality control varies from one market to another, product quality levels can vary, which is something that global companies must bear in mind when establishing their strategies due to the huge impact this might have on consumer loyalty, mental image and market position.

It was found that there is an inter-relationship between the variables of Emotional Intelligence and Marketing Effectiveness as the study confirmed the presence of correlation between both Self-awareness and Self-management and all the variables of Marketing Effectiveness; this relationship is direct. In addition, 
there are some limited relations between Social Awareness and integration and control of major marketing functions, and gathering adequate marketing information. Moreover, it has been found that there are limited relations between Relationship Management and gathering adequate marketing information, and existence of strategic orientation.

This is besides all the reciprocal relationships that have evolved between Emotional Intelligence and Marketing Effectiveness variables, as this relation is direct. There is an impact of Marketing Effectiveness variables on Customer Loyalty, and this impact is clearer than the impact of Emotional Intelligence. There is also an impact of Marketing Effectiveness variables on Brand Images, and this impact is clearer than the impact of Emotional Intelligence. Furthermore, there is an impact of Marketing Effectiveness variables on Marketing Position, and this impact is almost equivalent to the impact of Emotional Intelligence on Marketing Position.

\section{Recommendations}

There should be a complete integration among all executive managements to serve the strategic goals of the business enterprise. The marketing management does not work in isolation from other bodies. For example, Human Resources Management should be more selective in choosing managers, leaders and sales representatives that possess a high level of self-awareness and self-management as this has a great impact on achieving more efficiency at marketing operations as a whole. The higher emotional intelligence marketing managers possess, the more they comprehend the essential role that they should adopt in order to help consumers decide on product positioning and mental image. This is the main finding of this study which conformed to the findings of all previous studies presented above (Table 1) exploring the impact of Emotional Intelligence variables on Consumer Loyalty.

The study calls upon all business organizations and institutions in Egypt and in many Arab and developing countries to properly and efficiently adopt and activate emotional intelligence if they are to benefit from the subsequent increase in marketing efficiency, mental image and market positioning of their products, which will consequently be reflected on levels of consumer loyalty. The researcher concludes that there must be a greater focus on the emotional side than the cognitive side in the Arab countries and especially in Egypt, where advertising and promotional campaigns should be directed towards emotions to achieve the highest degrees of consumer devotion and loyalty. These results were confirmed by Fernandes and João Proença (2013), Cronin and Taylor (1992), Jones and Taylor (2007) and Kumar et al., (2003) as in Table 1. Future researchers could refer to the social and psychological studies of these countries and benefit from Sciences Integration Theory in a way that serves national strategic goals.

1- It is necessary to pay attention to the variables of Marketing Effectiveness because of its basic and fundamental role in raising consumer loyalty to the product.

2- We must employ the elements of strategic direction of an organization as commensurate with the circumstances and needs of consumers to maintain their loyalty.

3- Due care must be given to the elements of both variables (integrated marketing efforts and the efficiency of operations) because of their vital role in achieving an increase of loyalty level in the light of a company's existence and spread in multiple markets. 
4- It is necessary to pay attention to the variables of Marketing Effectiveness and, in particular, both the efficiency of operations and marketing information in order to improve the Brand image of the product among consumers.

5- It is necessary to pay attention to the variables of Marketing Effectiveness, represented greatly in the dimensional marketing, as the elements of integrated marketing must be re-employed, and that will help to establish great niche marketing for the consumers of a product. Also, due care shall be given to the following variables, namely self-awareness, self-management and management of special variables of Emotional Intelligence, which in turn will raise the profits and widen the niche market of a product.

6- It is necessary to pay attention during the selection process and hire people who have Emotional Intelligence in terms of self-awareness and self-management (self-control) because of its active role in achieving the variables of Marketing Effectiveness. 


\section{References}

- Akbari, Zahra and Hasan Safarnia. (2012). "The Relationship of Emotional Intelligence, Market orientation and Competitive strategy", Interdisciplinary Journal of Contemporary Research in Business", Institute of Interdisciplinary Business Research 497, Vol 4, No. 8.

- Angulo, Fernando; Albena Pergelova and Josep Rialp. (2010). "A Market Segmentation Approach For Higher Education Based on Rational and Emotional Factors", Journal of Marketing for Higher Education, Vol. 20, No. 1, 1-17, DOI: 10.1080/08841241003788029

- Antonetti, Paolo; Paul Baines and Lorna Walker. (2015). “From Elicitation to Consumption: Assessing the Longitudinal Effectiveness of Negative Emotional Appeals in Social Marketing", Journal of Marketing Management, 31: pp. 9-10, 940-969, DOI: 10.1080/0267257X.2015.1031266. In Marketing Places and Spaces. Published online, 93-105.

- Balamohan, Preethi; Vellore, Tamil Nadu and S. Gomathi. (2015). Emotional Intelligence: Its Importance and Relationship with Individual Performance, Team-Effectiveness, Leadership and Marketing Effectiveness, Doi:10.5901/mjss.2015.v6n1p120

- Beltagui, Ahmad; Marina Candi and Johann C. K. H. Riedel. (2015). “Design in the Experience Economy: Using Emotional Design for Service Innovation in Interdisciplinary Approaches to Product Design", Innovation \& Branding in International Marketing, pp. 111-135. 2015. Published online: http://dx.doi.org/10.1108/S1474-7979(2012)0000023009

- Best, Amy L. (2014). "Youth Consumers and the Fast-food Market, Food, Culture \& Society: An International", Journal of Multidisciplinary Research, 17:2, 283-300, 2014, http://dx.doi.org/1 $0.2752 / 175174414 \times 13871910531980$

- Billing, Paige. (2012). AStudy of Emotional Intelligence, Thinking Styles and Selling Effectiveness of Pharmaceutical Sales Representatives, (January 1), Dissertations Available from ProQuest, Paper AAI3530063, http://repository.upenn.edu/dissertations/AAI3530063

- Blocker, Christopher P. (2009). The Emotionally Intelligent Salesperson, Keller Center Research Report, Baylor University. Trademark/DMCA Page 1 information." Privacy Statement. Baylor University Waco, Texas 76798 1-800-BAYLOR. 2009

- Bone, Debora. (2002). "Dilemmas of Emotion Work in Nursing Under Market-Driven Health Care", International Journal of Public Sector Management, Vol. 15, no. 2, pp. 140-150, http://dx.doi. org/10.1108/09513550210419564

- Boninger, David S.; Faith Gleicher and Alan Strathman .(1994). “Counterfactual Thinking: From What Might Have Been to What May Be", Journal of Personality \& Social Psychology, 67 (2), 297-307.

- Boulding, William; Ajay Kalra; Richard Staelin and Valarie A. Zeithaml. (1993). "A Dynamic Process Model of Service Quality: From Expectations to Behavioral Intentions", Journal of Marketing Research, 30 (1) 7-27. 
- Chebat, Jean-Charles. (2002). "The Interplay of Cognitions and Emotions in Building Services Customer's Retention", in: Arch G. Woodside, Ellen M. Moore (ed.) Essays by Distinguished Marketing Scholars of the Society for Marketing Advances, Advances in Business Marketing and Purchasing, Vol. 11, Emerald Group Publishing Limited, pp.17-56.

- Chebat, Jean-Charles. The Interplay of Cognitions and Emotions in Building Services Customers Retention, In: Essays by Distinguished Marketing Scholars of the Society for Marketing Advances. Published online: 12 Mar 2015; 17-56. Permanent link to this document: http://dx.doi.org/10.1016/ S1069-0964(02)11004-0

- Dean, Dianne; Robin Croft and Christopher Pich. (2015). “Toward a Conceptual Framework of Emotional Relationship Marketing: An Examination of Two UK Political Parties", Journal of Political Marketing, 14:1-2, 19-34, 2015, DOI: http://dx.doi.org/10.1080/15377857.2014.990849

- Durkin, Mark; Seamas McKenna and Darryl Cummins. (2012). “Emotional Connections In Higher Education Marketing", International Journal of Educational Management, Vol. 26, Issue 2, pp. 153-161, http://dx.doi.org/10.1108/09513541211201960.

- Ebitu, Ezekiel Tom. (2016). Department of Marketing, Faculty of Management Sciences. University of Calabar, Calabar, Nigeria, Tel: 234-803-945-1333,

- General Authority for Investment and Free Zones, Arab Republic of Egypt. (2016). Information and Documentation Sector.

- General Authority for Investment and Free Zones, Arab Republic of Egypt. (2017). Information and Documentation Sector.

- Goleman, D. (1995). Emotional Intelligence. Bantam, New York, NY.

- Goleman, D. (2001). “Leadership That Gets Results”, Harvard Business Review, March/April.

- Gould, B. (1998). "Emotional Capital and Internal Marketing," The Antidote, Vol. 3, No. 8, pp. 34- 37, http://dx.doi.org/10.1108/EUM0000000006613

- Gunkel, Marjaana; Christopher Schlaegel and Robert L. Engle. (2014). "Culture and a Cascading Model of Emotional Intelligence: An Exploratory Analysis", Multinational Enterprises, Markets and Institutional Diversity. Published online, 229-257, http://dx.doi.org/10.1108/ S1745-886220140000009009

- Hashem, Tareq N. (2010). “Impact of Managers Emotional Intelligence on Marketing Creativity in Jordan Commercial Banks", Innovative Marketing, Vol. 6, Issue 3.

- Heffernan, Troy; Grant O’Neill; Tony Travaglione and Marcelle Droulers. (2008). "Relationship Marketing: The Impact of Emotional Intelligence and Trust on Bank Performance", International Journal of Bank Marketing, Vol. 26, Issue 3, pp. 183-199. http://dx.doi. org/10.1108/02652320810864652

- Hinck, Wolfgang and Zafar U. Ahmed. (2015). “The Effect of Anticipatory Emotions on Students Performance in Marketing Simulations", Journal of Research in Marketing and Entrepreneurship, Vol. 17, Issue 1, pp. 5-22. http://dx.doi.org/10.1108/JRME-12-2014-0034. 
- Johnson, Allison R. and David W. Stewart. (2015). “A Reappraisal of The Role of Emotion in Consumer Behavior", Review of Marketing Research, 2015. Published online: http://dx.doi. org/10.1108/S1548-6435(2004)0000001005

- Kidwell, Blair; David M. Hardesty; Brian R. Murtha and Shibin Sheng. (2012). "A Closer Look at Emotional Intelligence in Marketing Exchange", Marketing Intelligence Review, Vol. 4, Issue 1, pp. 24-31, ISSN 1865-5866 (Online), DOI: 10.2478/gfkmir-2014-0038

- Kotler, P. (1977). "From Sales Obsession to Marketing Effectiveness", Harvard Business Review, Vol. 55, pp. 67-75.

- Kotler, P. (1997). Marketing Management, Analysis Planning, Implementation and Control, Prentice-Hall, Upper Saddle River, NJ., 1997.

- Kwak, Dae Hee; Yu Kyoum Kim and Edward R. Hirt. (2011). "Exploring the Role of Emotions on Sport Consumers' Behavioral and Cognitive Responses to Marketing Stimuli", European Sport Management Quarterly, 11:3, 225-250.

- Lee, Jung-Hyun; Min-su Kim Aeeun Jeon. (2013). “The Effects of Emotional Intelligence on Service Recovery and Organizational Loyalty: A Case of Flight Attendants of South Korean Airlines", A. Serv Bus, Empirical Article, Vol. 7, Issue 4, DOI: 10.1007/s11628-012-0181-7.

- Mandina, Siphiwe P.; Tendai Ngwenya and Munesu Muzadzi. (2014). “Effectiveness of Emotional Marketing on Brand Loyalty in State Run Universities", European Journal of Business and Management, Vol. 6, No.13, www.iiste.org.

- Mayer, J. D.; Salovey, P. and Caruso, D. R. (2000). "Models of Emotional Intelligence", Sternberg, R. J. (Ed.), Handbook of Human Intelligence, Cambridge University Press, New York, NY, pp. 396-420.

- Mazurek, Marica. (2015). "The Emotional Attachment Built through the Attitudes and Managerial Approach to Place Marketing and Branding - The Golden City of Kremnica, Slovakia", In: Antónia Correia; Juergen Gnoth; Metin Kozak; Alan Fyall (ed.) Marketing Places and Spaces: Advances in Culture, Tourism and Hospitality Research, Vol. 10," Emerald Group Publishing Limited, pp.93105. DOI: http://dx.doi.org/10.1108/S1871-317320150000010007

- Mbum, Patrick Awok and Abigail Edem Okon. (2012). "An Exploration of Emotional Intelligence and Market Segmentation, Targeting and Positioning in Selected Central Business Districts in Nigeria", International Journal of Marketing Studies, Vol. 4, No. 3. DOI: http://dx.doi.org/10.5539/ijms. v4n3p173

- Mohd, Jamaliah; Yosof, Shahira Ariffin. (2016). "The Influence of Self-Congruity, Functional Image and Emotional Attachment on Loyalty", Procardia Economics and Finance, Vol. 37.

- Nwokah, N. Gladson; Augustine I. Ahiauzu. (2010). “Marketing in Governance: Emotional Intelligence Leadership For Effective Corporate Governance, Corporate Governance", The International Journal of Business in Society, Vol. 10, Issue 2, pp. 150-160, http://dx.doi. org/10.1108/14720701011035675.

- Prentice, Catherin. (2016). "Leveraging Employee Emotional Intelligence in Casino Profitability", Journal of Retailing and Consumer Services, Vol. 33, November. 
- Rahimpour, Amir and Vahid Reza Mirabi. (2015). "The Relationship between Marketing Emotional Intelligence and Marketing Exchange Variables: The Case of Iranian Sales People", Indian Journal of Fundamental and Applied Life Sciences, Online International Journal Available at: www.cibtech.org/sp.ed/jls/2015/02/jls.htm, 2015, Vol. 5 (S2), pp. 283-300.

- Staton, Mark. Neeru Paharia and Christopher Oveis. (2012). “Emotional Marketing: How Pride and Compassion Impact Preferences for Underdog and Top Dog Brands", NA - Advances in Consumer Research, Vol. 40, eds. Association for Consumer Research, pp. 1045-1046.

- Tavakoli-Targhi, P. (2014). “Priority Investment Components of Emotional Intelligence Effective on Marketing with AHP Method", IEEE International Conference on Industrial Engineering and Engineering Management, 9-12 Dec., pp. 159-163. ISSN 2157-3611, INSPEC Accession No. 14983781.

- Teng, C. C. and VW Liu. (2013). "The Pre-holiday Effect and Positive Emotion in the Taiwan Stock Market, 1971-2011", Investment Analysts Journal, 42:77, 35-43, http://dx.doi.org/10.1080/10 293523.2013.11082554

- Trivellas, P. and N. Kakkos. (2015). “Understanding The Impact of Procedural Justice, Job Characteristics and Resources on Emotional Exhaustion and Its Marketing-related Implications", Anatolia: An International Journal of Tourism and Hospitality Research, 26: 1, pp. 45-60, DOI: 10.1080/13032917.2014.990709.

- Uvalcaba-Romero, Norma Alicia; Pablo Fernandez-Berrocal; Jose Guadalupe Salazar-Estrada and Julia Gallegos-Guajardo. (2017). “Positive Emotions, Self-esteem, Interpersonal Relationships and Social Support as Mediators between Emotional Intelligence and Life Satisfaction", Journal of Behavior, Health \& Social Issue, Vol. 9 , Issue 1, May-October.

- Yaghoubi, Nour-Mohammad and Habibollah Doaee. (2011). “The Effect of Emotional Intelligence on Relationship Marketing", Interdisciplinary Journal of Contemporary Research in Business, Institute of Interdisciplinary Business Research, 901, Sept., Vol. 3, No, 5, ijcrb.webs.com. 